\title{
A Case of Resistance to Thyroid Hormone with Chronic Thyroiditis: Discovery of a Novel Mutation (I54V)
}

\author{
I. Kammoun, C. Bouzid, H. Kandara, L. Ben Salem, Z. Turki, and C. Ben Slama \\ Endocrinology and Diabetology Department, National Nutrition Institute, 1007 Tunis, Tunisia \\ Correspondence should be addressed to I. Kammoun, ines.kamoun@planet.tn \\ Received 18 July 2011; Accepted 14 August 2011 \\ Academic Editors: G. Aimaretti and H. G. Dorr \\ Copyright () 2011 I. Kammoun et al. This is an open access article distributed under the Creative Commons Attribution License, \\ which permits unrestricted use, distribution, and reproduction in any medium, provided the original work is properly cited.
}

Resistance to thyroid hormone (RTH) is a rare disorder characterized by variable tissue hyporesponsiveness to thyroid hormone, usually caused by mutations in the thyroid hormone receptor beta $(\mathrm{TR} \beta)$. It has been reported that the serum of patients with $\mathrm{RTH}$ is free of auto-antibodies against thyroglobulin ( $\mathrm{Tg}$ ) and thyroid peroxidase (TPO), except in rare cases where coincidental autoimmune thyroiditis is also present. We describe a 13-year-old girl with chronic thyroiditis and RTH. This patient had increased plasma free T3, free T4 at the upper limits with unsuppressed TSH. She had peripheral manifestations of thyroid hormone excess, hypertension and growth acceleration. Anti-TPO antibodies were positive. Sequence analysis of the TR $\beta$ gene was performed and revealed a novel mutation $\mathrm{I} 54 \mathrm{~V}$ in exon 4 . The same mutation was also found in the mother and two asymptomatic sisters. The clinical presentation of our patient is not habitual in RTH because growth retardation is frequently reported in this syndrome. The association between RTH and thyroiditis complicate the management of the hypothyroidism.

\section{Introduction}

Thyroid hormone resistance $(\mathrm{RTH})$ is a rare and usually autosomal dominant disorder characterized by reduced target tissues responsiveness to thyroid hormones. Since Refetoff et al. described this syndrome in 1967 [1], over 1000 cases have been identified [2]

Thyroid hormone secretion is stimulated by thyroidstimulating hormone (TSH), itself under a negative feedback by thyroid hormones. The RTH is characterized by high levels of circulating thyroid hormone and inappropriately normal or elevated value of TSH.

Formerly, RTH was subdivided into generalized RTH (GRTH) and pituitary RTH (PRTH) [3]. PRTH is extremely rare and, in general, its diagnosis is made largely on the basis of the presence of the clinical signs and symptoms of hyperthyroidism [4]. Based on symptoms and signs, this subclassification does not have a logical basis because these two presentations are encountered in individuals with the same mutation [5].

The linkage between RTH and the TR $\beta$ gene was found in 1988 [6]. Since then, approximately 100 mutations have been detected in this gene $[7,8]$. It has been reported that the serum of patients with RTH is free of autoantibodies against thyroglobulin (Tg) and thyroid peroxidase (TPO), except in the rare instances where coincidental autoimmune thyroiditis is also present [9].

In this study, we describe a 13-year-old girl with chronic thyroiditis and RTH. She had manifestations of peripheral thyroid hormone excess, hypertension, growth acceleration, inappropriate secretion of TSH, and increased anti-TPO antibodies. Genetic analysis revealed a novel mutation I54V in exon 4 of the TR $\beta$ gene. This mutation was found in the index case, her mother, and two asymptomatic sisters.

\section{Case Report}

A 13-year-old girl was seen in 2007 because of hypertension treated since 2005 by Acebutolol $400 \mathrm{mg} /$ day and Captopril $50 \mathrm{mg} /$ day. She had a full-term birth, followed by a normal development during the neonatal period. When first seen at our clinic, she weighed $67 \mathrm{~kg}$ ( $>97$ percentile), her height was $174 \mathrm{~cm}(+3 \mathrm{SD})$, her blood pressure was $150 / 10 \mathrm{mmHg}$, and her pulse rate was 90 beats/min. Her thyroid gland was normal but she had clinical symptoms of hyperthyroidism 
TABLE 1: Biochemical findings of the family members.

\begin{tabular}{lcc}
\hline & FT4 $(\mathrm{pmol} / \mathrm{L})$ & TSH $(\mu \mathrm{UI} / \mathrm{mL})$ \\
\hline The index patient & \multicolumn{2}{c}{ See the text and Table 2} \\
Father & 13.1 & 1.03 \\
Mother & 17.6 & 3.86 \\
1st sister & 17.8 & 1.53 \\
2nd sister & 17.8 & 2.31 \\
3rd sister & 17.4 & 1.55 \\
4th sister & 18.3 & 1.49 \\
5th sister & 20.2 & 1.9 \\
Normal range & $10.3-24.4$ & $0.4-4.0$ \\
\hline
\end{tabular}

(finger tremor and moist skin) but no ocular signs or symptoms. She had no family history of thyroid diseases. At that time, her thyroid function tests revealed free T4, 17.9 than $25 \mathrm{pmol} / \mathrm{L}$ (normal range 10.3-24.4), and TSH, 7.84 than $5.68 \mu \mathrm{UI} / \mathrm{mL}$ (normal range $0.4-4.0$ ). These tests were controlled by radioimmunological assay, and the investigations showed free T4, $15.2 \mathrm{pmol} / \mathrm{L}$ (normal range, 11-25), free T3, $9.5 \mathrm{pmol} / \mathrm{L}$ (normal range, 3.9-6.8), and $\mathrm{TSH}, 18.5 \mu \mathrm{UI} / \mathrm{mL}$. (normal range, 0.17-4.0). All the other causes of secondary hypertension were eliminated (renal causes, Cushing's syndrome, acromegaly, pheochromocytoma, and hypermineralocorticism). Anti-TPO antibodies (238 UI/mL) were positive suggesting mild chronic thyroiditis. Ultrasonography showed no goiter but a heterogeneous thyroid. All family members had normal FT4 and TSH levels (Table 1).

The level of TSH $\alpha$-subunit was $0.33 \mu \mathrm{IU} / \mathrm{mL}$ (range, $0.05-0.9$ ) and the ratio TSH $\alpha$-subunit/TSH was 1 . Magnetic resonance imaging of the sellar region showed no abnormal findings (Figure 1). Sequence analysis of the $\operatorname{TR} \beta$ gene was performed in the index case, her both parents, her five sisters, and her four nephews. All members gave their informed consent to participate in this study. Leukocyte DNA was extracted from blood samples using standard methods. The result revealed a novel mutation $\mathrm{I} 54 \mathrm{~V}$ in exon 4 of the $\mathrm{TR} \beta$ gene with a substitution of isoleucine for valine, and the patient was diagnosed as having a case of THR syndrome. The same mutation was also found in the mother and two asymptomatic sisters (Figure 2).

Propranolol (20 mg bid) and Enalapril (20 mg/day) were given to our patient, and her hypertension and hyperthyroidism symptoms were controlled.

Periodic thyroid function tests during followup showed FT4 at the upper limit with unsuppressed TSH until September 2009. In January 2010, the patient presented with symptoms of hypothyroidism: weight gain and slow mentation, and presence of peripheral hypothyroidism: FT4 at $4.31 \mathrm{pmol} / \mathrm{L}$ and TSH at $242.4 \mu \mathrm{UI} / \mathrm{mL}$ (Table 2). Our patient presents therefore a rare association of THR with chronic thyroiditis. Treated with levothyroxine $(100 \mu \mathrm{g} /$ day $)$, her last thyroid function tests (May 2010) were normal: FT4, $15.57 \mathrm{pmol} / \mathrm{L}$, and TSH, $2.34 \mu \mathrm{UI} / \mathrm{mL}$.

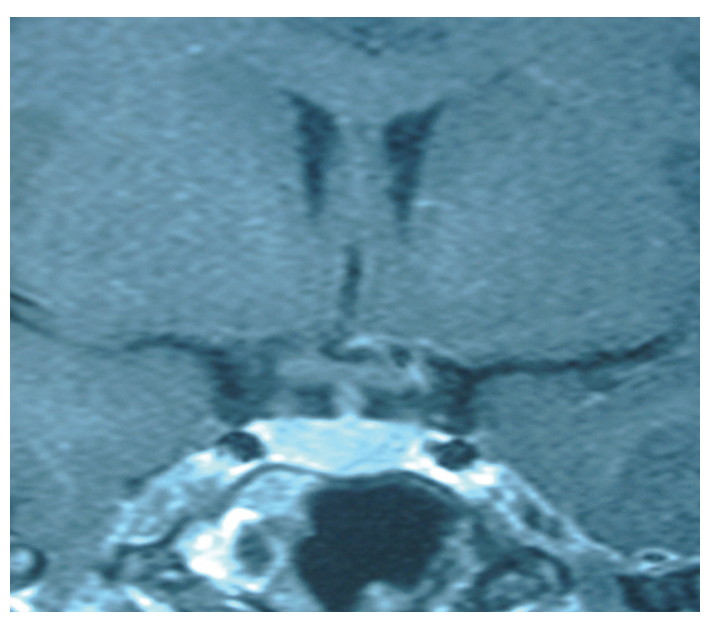

FIGURE 1: Magnetic resonance imaging of the sellar region of our patient: no abnormal findings.

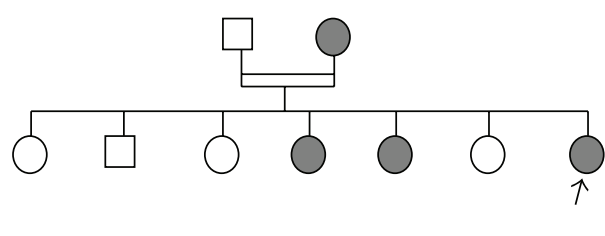

Mutation $154 \mathrm{~V}$ du TR $\beta$

Figure 2: Pedigree of the family.

\section{Discussion}

Our index case had high levels of FT3, FT4 at the upper limit, inappropriate lack of TSH suppression, and clinical symptoms of hyperthyroidism. The TSH $\alpha$-subunit/TSH ratio was 1 , and the MRI showed no pituitary adenoma. These findings exclude the possibility of TSH-producing pituitary adenoma and suggest the presence of RTH.

RTH is found in about 1 case per 40,000 live births [10]. Familial occurrence of RTH has been documented in approximately $75 \%$ of cases [2]. Inheritance is usually autosomal dominant [2], and transmission was clearly recessive in only one family [1].

RTH is classified into two phenotypes: GRTH and PRTH. Patients with GRTH are typically euthyroid or hypothyroid, whereas patients with PRTH (such as our patient) are usually hypermetabolic [11]. No differences in the absolute levels of TSH or free thyroid hormone are observed in GRTH patients as opposed to PRTH patients. A molecular mechanism to explain these two clinical phenotypes has proven elusive, and many authors have concluded that they are part of a spectrum of the same disorder $[4,5]$.

Thyroid hormone receptors (TRs) are ligand-dependent transcription factors, which mediate the biological activities of T3. TRs are encoded for by the THRA and THRB genes, which are located on chromosomes 3 and 17, respectively [12]. Although THRA1 and THRB1 are ubiquitously expressed, THRA1 is expressed primarily in the heart, bone, and brain, whereas THRB1 is more abundant in the liver, 
TABLE 2: Evolution of the biochemical findings of the index patient.

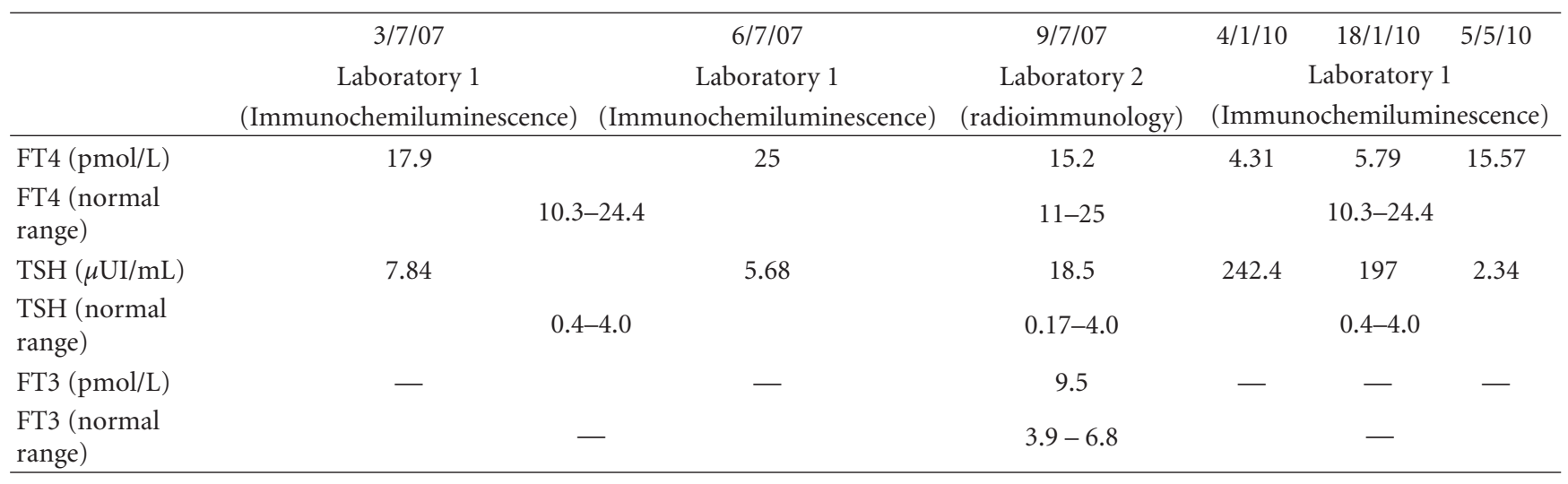

kidney, and thyroid. THRB2 expression is limited to the pituitary, hypothalamus, retina, and inner ear, and THRB3 expression has been detected principally in the heart and kidney $[10,13]$.

Most cases of RTH are caused by mutations in the THRB gene. However, RTH without a structural THRB defect occurs in approximately $10 \%$ of the cases [14]. Since the first demonstration of non-TR RTH [15], 29 subjects belonging to 23 different families have been identified [2, 16-18].

It has been postulated that a cofactor interacting with THR may be responsible for the manifestation of RTH [14]. Subjects with the same mutation may exhibit different phenotypes like our patient and her two sisters, suggesting modulation of thyroid hormone actions by other factors.

Patients who present with apparent selective pituitary resistance are the most difficult to manage. If they exhibit hyperthyroid features at tissue levels (like our patient), they generally require treatment to reduce the elevated thyroid hormone levels. 3,5,3'-Triiodothyroacetic acid (TRIAC), a physiological metabolite of T3, can reduce TSH and endogenous thyroid hormone levels and alleviate symptoms [19]. However, the efficacy of TRIAC is variable [20] and its effect on heart rate is often minimal, probably because the decrease in thyroid hormone levels is offset by the intrinsic thyromimetic effect of the drug. Our patient did not receive TRIAC, and her symptoms of hyperthyroidism improved after treatment with propranolol.

Concomitant autoimmune thyroiditis in patients with RTH is rarely reported $[9,21,22]$. As our patient was positive for anti-TPO antibodies, we diagnosed her as having RTH with coincidental autoimmune thyroiditis. This thyroiditis may explain the lack of important elevation of FT4. The hypothyroidism that she developed in 2010 is due to aggravation of the chronic thyroiditis and required treatment with thyroid hormone.

In conclusion, we have described the 3-year history of a young girl with RTH and chronic thyroiditis. She showed a particular phenotype that included clinical hyperthyroidism, hypertension, and accelerated growth, without goiter or ocular signs. This clinical presentation is not habitual in RTH because growth retardation is frequently reported in this syndrome. The association between RTH and thyroiditis complicates the management of the hypothyroidism because the TSH concentration cannot be a reliable marker in monitoring replacement therapy with thyroid hormone.

Our patient has a novel mutation I54V in the TRB gene. Her mother and her two sisters were asymptomatic although they have the same mutation, and they need a long-term followup for the eventual appearance of an abnormal thyroid function.

\section{Acknowledgments}

The authors thank Professor Patrice Rodien, Professor Yvef Malthiery, and Dr. Frederique Favagner (Angers Hospital, France) for their help in molecular study and Professor Rafik Boukhris (Endocrinology, Tunis) for his assistance in this work.

\section{References}

[1] S. Refetoff, L. T. DeWind, and L. J. DeGroot, "Familial syndrome combining deaf-mutism, stuppled epiphyses, goiter and abnormally high PBI: possible target organ refractoriness to thyroid hormone," Journal of Clinical Endocrinology and Metabolism, vol. 27, no. 2, pp. 279-294, 1967.

[2] S. Refetoff, "Resistance to thyroid hormones," in The Thyroid, L. E. Braverman and R. D. Utiger, Eds., pp. 1109-1129, Lippincott Williams \& Wilkins, Philadelphia, 2005.

[3] J. D. Safer, M. F. Langlois, R. Cohen et al., "Isoform variable action among thyroid hormone receptor mutants provides insight into pituitary resistance to thyroid hormone," Molecular Endocrinology, vol. 11, no. 1, pp. 16-26, 1997.

[4] P. Beck-Peccoz and V. K. K. Chatterjee, "The variable clinical phenotype in thyroid hormone resistance syndrome," Thyroid, vol. 4, no. 2, pp. 225-232, 1994.

[5] S. Refetoff and A. M. Dumitrescu, "Syndromes of reduced sensitivity to thyroid hormone: genetic defects in hormone receptors, cell transporters and deiodination," Best Practice and Research: Clinical Endocrinology and Metabolism, vol. 21, no. 2, pp. 277-305, 2007.

[6] S. J. Usala, A. E. Bale, N. Gesundheit et al., "Tight linkage between the syndrome of generalized thyroid hormone resistance and the human c-erbA $\beta$ gene," Molecular Endocrinology, vol. 2, no. 12, pp. 1217-1220, 1988. 
[7] F. Brucker-Davis, M. C. Skarulis, M. B. Grace et al., "Genetic and clinical features of 42 kindreds with resistance to thyroid hormone," Annals of Internal Medicine, vol. 123, no. 8, pp. 572-583, 1995.

[8] P. Beck-Peccoz, V. K. Chatterjee, W. W. Chin et al., "Nomenclature of thyroid hormone receptor $\beta$-gene mutations in resistance to thyroid hormone: consensus statement from the first workshop on thyroid hormone resistance," Journal of Clinical Endocrinology and Metabolism, vol. 78, pp. 990-993, 1993.

[9] B. A. Lamberg, S. Rosengard, and K. Liewendahl, "Familial partial peripheral resistance to thyroid hormones," Acta Endocrinologica, vol. 87, no. 2, pp. 303-312, 1978.

[10] S. H. LaFranchi, D. B. Snyder, D. E. Sesser et al., "Follow-up of newborns with elevated screening T4 concentrations," Journal of Pediatrics, vol. 143, no. 3, pp. 296-301, 2003.

[11] A. P. S. Kong, C. W. Lam, A. O. K. Chan, S. F. Yiu, and S. C. Tiu, "Resistance to thyroid hormone in a Chinese family with R429Q mutation in the thyroid hormone receptor $\beta$ gene," Hong Kong Medical Journal, vol. 11, no. 2, pp. 125-129, 2005.

[12] H. K. Ji, S. P. Tae, S. B. Hong, H. K. Gu, W. Y. Han, and H. P. Ji, "A newly identified insertion mutation in the thyroid hormone receptor- $\beta$ gene in a Korean family with generalized thyroid hormone resistance," Journal of Korean Medical Science, vol. 22, no. 3, pp. 560-563, 2007.

[13] G. R. Williams, "Cloning and characterization of two novel thyroid hormone receptor $\beta$ isoforms," Molecular and Cellular Biology, vol. 20, no. 22, pp. 8329-8342, 2000.

[14] J. Pohlenz, R. E. Weiss, P. E. Macchia et al., "Five new families with resistance to thyroid hormone not caused by mutations in the thyroid hormone receptor $\beta$ gene," Journal of Clinical Endocrinology and Metabolism, vol. 84, no. 11, pp. 3919-3928, 1999.

[15] R. E. Weiss, Y. Hayashi, T. Nagaya et al., "Dominant inheritance of resistance to thyroid hormone not linked to defects in the thyroid hormone receptor $\alpha$ or $\beta$ genes may be due to a defective cofactor," Journal of Clinical Endocrinology and Metabolism, vol. 81, no. 12, pp. 4196-4203, 1996.

[16] P. M. Sadow, S. Reutrakul, R. E. Weiss, and S. Refetoff, "Resistance to thyroid hormone in the absence of mutations in the thyroid hormone receptor genes," Current Opinion in Endocrinology and Diabetes, vol. 7, no. 5, pp. 253-259, 2000.

[17] V. Vlaeminck-Guillem, A. Margotat, J. Torresani, M. D'Herbomez, M. Decoulx, and J. L. Wemeau, "Resistance to thyroid hormone in a family with no $\operatorname{TR} \beta$ gene anomaly: pathogenic hypotheses," Annales d'Endocrinologie, vol. 61, no. 3, pp. 194-199, 2000.

[18] S. Parikh, S. Ando, A. Schneider, M. C. Skarulis, N. J. Sarlis, and P. M. Yen, "Resistance to thyroid hormone in a patient without thyroid hormone receptor mutations," Thyroid, vol. 12 , no. 1, pp. 81-86, 2002.

[19] S. Refetoff, Resistance to Thyroid Hormone: Current Therapy in Endocrinology and Metabolism, Mosby, St Louis, Mo, USA, 6th edition, 1997.

[20] J. M. Kunitake, N. Hartman, L. C. Henson et al., "3,5,3'triiodothyroacetic acid therapy for thyroid hormone resistance," Journal of Clinical Endocrinology and Metabolism, vol. 69, no. 2, pp. 461-466, 1989.

[21] H. Sato and H. Sakai, "A family showing resistance to thyroid hormone associated with chronic thyroiditis and its clinical features: a case report," Endocrine Journal, vol. 53, no. 3, pp. 421-425, 2006.
[22] H. Sato, Y. Koike, M. Honma, M. Yagame, and K. Ito, "Evaluation of thyroid hormone action in a case of generalized resistance to thyroid hormone with chronic thyroiditis: discovery of a novel heterozygous missense mutation (G347A)," Endocrine Journal, vol. 54, no. 5, pp. 727-732, 2007. 


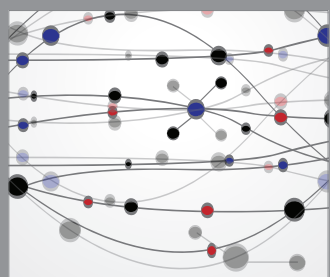

The Scientific World Journal
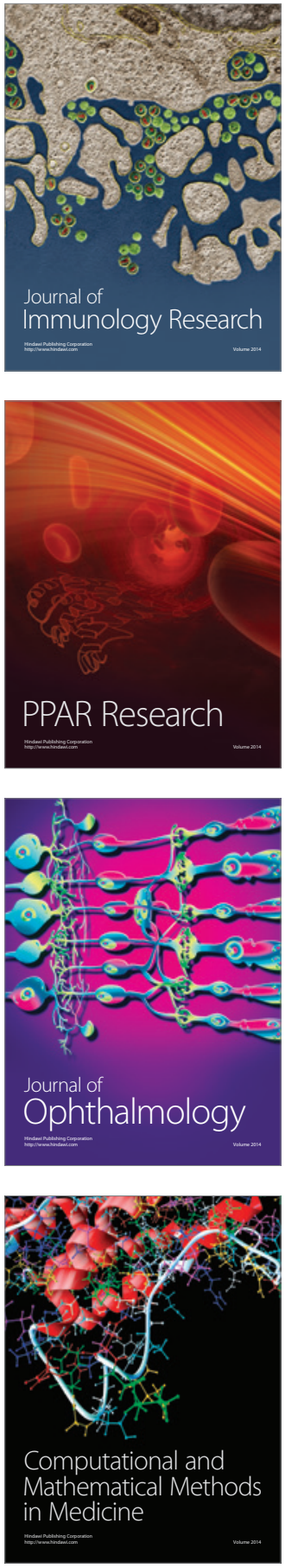

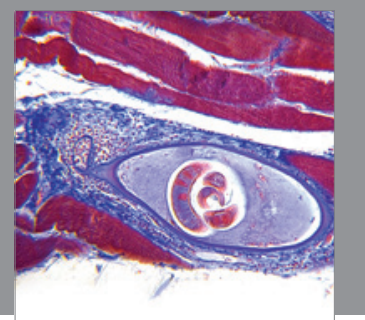

Gastroenterology

Research and Practice
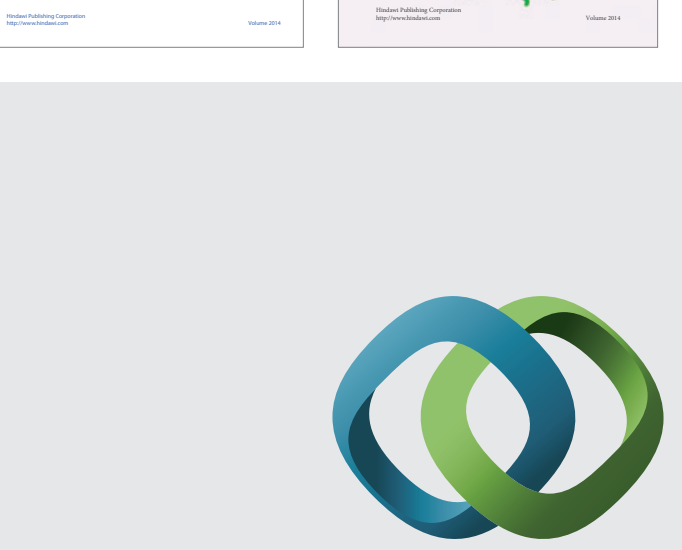

\section{Hindawi}

Submit your manuscripts at

http://www.hindawi.com
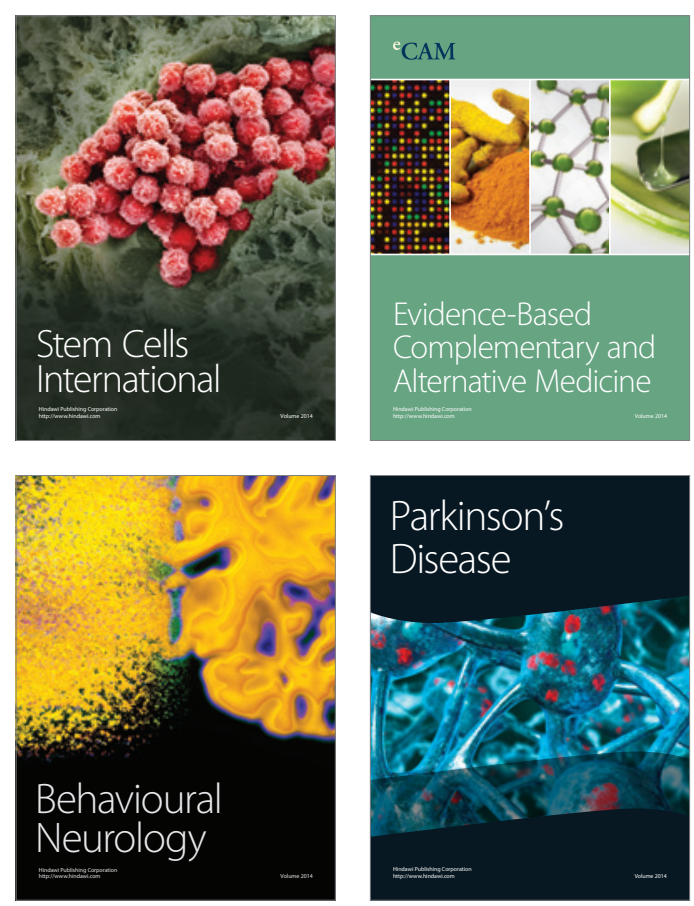

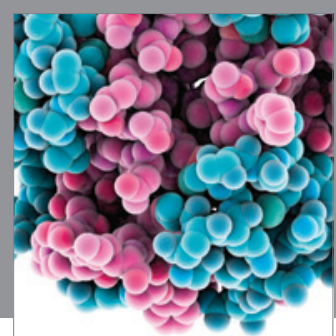

Journal of
Diabetes Research

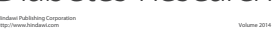

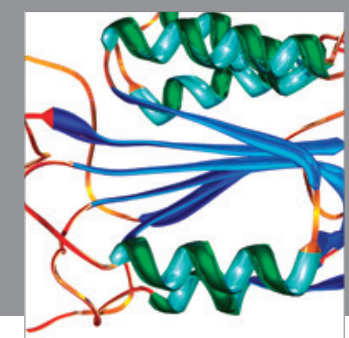

Disease Markers
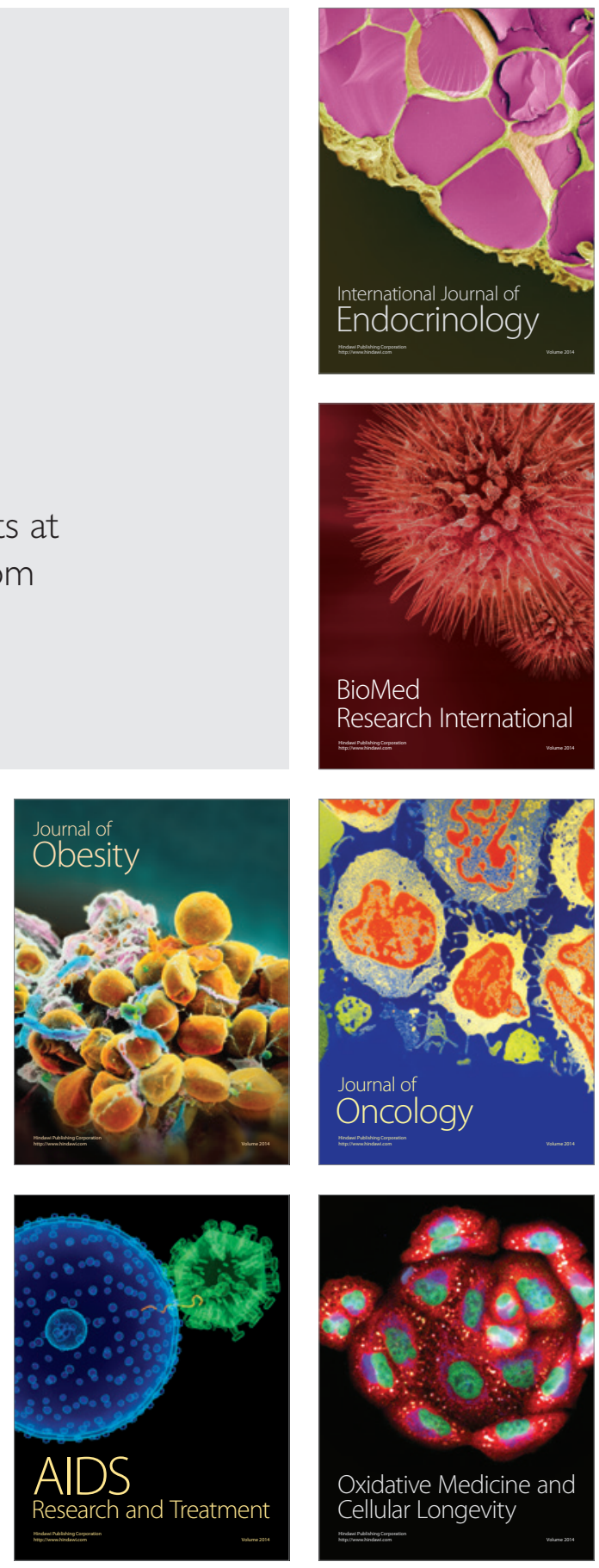